\title{
AUTORADIOGRAPHIC LOCALIZATION OF THYROTROPIN- RELEASING HORMONE RECEPTORS IN THE RAT CENTRAL NERVOUS SYSTEM ${ }^{1}$
}

\author{
SCOTT MANAKER, ${ }^{*}$ ANDREW WINOKUR, $\$ \S$ WILLIAM H. ROSTENE, $\|$ AND \\ THOMAS C. RAINBOW§
}

Departments of ${ }^{*}$ Biology, $\uparrow$ Psychiatry, $§$ Pharmacology, and the School of Medicine, University of Pennsylvania, Philadelphia, Pennsylvania 19104 and $\|$ Unité de Recherche de Diabetologue et d'Etudes Radio-Immunologiques des Hormone Proteiques (INSERM U.55, CNRS ERA 191), Hôpital Saint-Antoine, 75571 Paris Cedex 12, France

Received March 16, 1984; Revised May 3, 1984; Accepted June 15, 1984

\begin{abstract}
We employed quantitative autoradiography to examine the distribution of thyrotropin-releasing hormone (TRH) receptors in the rat CNS. The binding of $\left[{ }^{3} \mathrm{H}\right] 3$-methyl-histidine-TRH $\left(\left[{ }^{3} \mathrm{H}\right] \mathrm{MeTRH}\right)$ to TRH receptors in frozen rat brain sections was saturable, of a high affinity $\left(K_{\mathrm{d}}=5 \mathrm{nM}\right)$, and specific for TRH analogs. Autoradiograms of $\left[{ }^{3} \mathrm{H}\right] \mathrm{MeTRH}$ binding showed highest concentrations of TRH receptors in the rhinencephalon, including accessory olfactory bulb, nuclei of the amygdala, and the ventral dentate gyrus and subiculum of the hippocampus. Moderate TRH receptor concentrations were found within the thalamus and hypothalamus, in most regions of the rhombencephalon, such as the cranial nerve nuclei, and in the substantia gelatinosa of the spinal cord. Neocortex and basal ganglia contained low densities of TRH receptors. This distribution correlates well with the sensitivity of brain regions to the known effects of TRH, and suggests that TRH receptors may mediate the actions of TRH in the rat CNS.
\end{abstract}

Thyrotropin-releasing hormone (TRH) was initially isolated and characterized on the basis of its hypophysiotropic actions (Boler et al., 1969; Burgus et al., 1969). Sequencing revealed its tripeptide structure as pyroglutamyl-histidyl-prolyl-amide. The development of a radioimmunoassay for TRH (Bassiri and Utiger, 1972) led to studies of its distribution throughout the central nervous system. In addition to being highly concentrated in the hypothalamus, TRH was demonstrated to be present in numerous sites throughout the brain (Brownstein et al., 1974; Jackson and Reichlin, 1974a; Oliver et al., 1974; Winokur and Utiger, 1974). To date, TRH has also been demonstrated within olfactory bulb (Kreider et al., 1981; Stanton et al., 1982; Dluzen and Ramirez, 1983), and spinal cord (Kardon et al., 1977; Leppaluoto et al., 1978). A wide variety of species have been shown to contain substantial amounts of TRH, including rat (Leppaluoto et al., 1978; Spindel and Wurtman, 1980), frog (Jackson and Reichlin, 1974b; Taurog et al., 1974), ground squirrel (Stanton et al., 1982), salamander (Taurog et al., 1974), chicken, snake, and salmon (Jackson and

\footnotetext{
${ }^{1}$ Portions of this work were completed by the first author in partial fulfillment of the Ph.D. degree from the University of Pennsylvania. The work has been supported by National Institutes of Health Medical Scientist Training Program Grant 5-T32-GM07170 to S. M., National Institute of Mental Health Research Scientist Development Award MH00044, and National Institutes of Health Grants NS 18332 to A. W., and NS 19597, NS 20006, and fellowships from the Alfred P. Sloan Foundation and the Esther A. and Joseph Klingenstein Fund to T. C. R. The authors also express their thanks to Pamela Knight, Marion Nakada, and Caroline Wieczorek for their expert technical assistance.
}

Reichlin, 1974b), and human (Okon and Koch, 1976; Kubek et al., 1977; Parker and Porter, 1983).

More specific regional localization of TRH has been evaluated by means of the nuclei-punch technique of Palkovits (1973). TRH is distributed in rat hypothalamic and forebrain nuclei (Brownstein et al., 1974), brainstem nuclei (Kubek et al., 1983) and grey matter of the spinal cord (Kardon et al., 1977). Immunocytochemical studies (Hokfelt et al., 1975a, 1975b) revealed TRH-containing cell bodies within the hypothalamus and brainstem, and TRH-containing fibers within the septal region of the rat.

Burt and Snyder (1975) first demonstrated receptor binding of tritiated TRH to membrane homogenates of rat brain tissue. Gross dissection of rat (Burt and Snyder, 1975), monkey (Ogawa et al., 1981), and sheep (Burt and Taylor, 1980) brains to investigate the regional distribution of $\mathrm{TRH}$ receptors showed high receptor concentrations in membrane homogenates from the hypothalamus, amygdala, hippocampus, midbrain, and cerebral cortex. However, the results of these studies were complicated by binding of the ligand to filter blanks, and by the presence of a low affinity binding site in the homogenates which alone could account for up to two-thirds of the specific binding seen (Burt and Snyder, 1975). These technical difficulties have been overcome by using tritiated (3-Me-His $\left.{ }^{2}\right)-\mathrm{TRH}$ (MeTRH), an analog known to have up to 10 -fold higher potency than TRH in both effecting hormonal release (Vale et al., 1971; Sowers et al., 1976a, 1976b; Dannies and Markell, 1980) and binding to pituitary membrane receptors (Grant et al., 1973; Hinkle et al., 1974). Studies of MeTRH binding to membrane homogenates from brain regions obtained by gross 
dissection from rat (Simasko and Horita, 1982), sheep (Taylor and Burt, 1981), chicken (Thompson et al., 1981), guinea pig, rabbit, cat, dog, cow, and pig (Taylor and Burt, 1982), mouse, and fish (Burt and Ajah, 1984) have all yielded consistent results. In addition, Sharif and Burt (1983) have demonstrated MeTRH binding throughout the rabbit spinal cord. However, binding assays of membrane homogenates obtained by crude dissection of brain regions cannot provide the same degree of resolution and discrete localization of receptors that can be obtained with quantitative autoradiography.

Several groups have demonstrated the feasibility of TRH receptor autoradiography in rat brain (Palacios, 1983; Rostene et al., 1983; Pilotte et al., 1984), guinea pig brain (Palacios, 1983), and rabbit spinal cord (Sharif and Burt, 1983). We report here the use of quantitative autoradiography to localize TRH receptors throughout the rat $\mathrm{CNS}$, and describe in detail the kinetic, biochemical, and competitive binding characteristics of $\left[{ }^{3} \mathrm{H}\right] \mathrm{MeTRH}$ to frozen slices of rat brain.

\section{Materials and Methods}

Animals. We assayed TRH receptor levels in brain and spinal cord tissue from male Sprague-Dawley rats (180-200 gm; Ace Animals, Inc., Boyertown, PA). The rats were housed under a 14:10-hr light-dark cycle, and maintained with Purina rat chow and water ad libitum until sacrifice.

Chemicals and TRH analogs. MeTRH was obtained from Bachem (Torrance, CA). TRH-OH (frec acid) was purchased from Cambridge Research Biochemicals (Atlantic Beach, NY). Both Glu-His-Pro- $\mathrm{NH}_{2}$ and pGlu-His-Pro-Gly- $\mathrm{NH}_{2}$ were obtained from Peninsula Laboratories (Belmont, CA). $\left[{ }^{3} \mathrm{H}\right] \mathrm{MeTRH}$ (specific activity, $76.7 \mathrm{Ci} / \mathrm{mmol}$ ) was purchased from New England Nuclear, Boston, MA. TRH, cyclo(-HisPro-), Pro- $\mathrm{NH}_{2}$, Tris- $\mathrm{HCl}, \mathrm{MgCl}_{2} \cdot 6 \mathrm{H}_{2} \mathrm{O}$, bovine serum albumin, and Bacitracin were all obtained from Sigma Chemical Co. (St. Louis, MO).

Tissue preparation. Animals were decapitated; their brains or spinal cords rapidly were removed, mounted on cryostat chucks, and frozen in dry ice. Coronal sections $32-\mu \mathrm{m}$ thick were cut at $-18^{\circ} \mathrm{C}$ and thawmounted onto chromate/gelatin-subbed slides. Sections were then stored with desiccant at $-70^{\circ} \mathrm{C}$. For characterization of $\left[{ }^{3} \mathrm{H}\right] \mathrm{MeTRH}$ binding by scintillation counting, consecutive coronal sections were cut through the amygdala at Paxinos and Watson (1982) levels 17 to 26 and mounted two per slide. For calculation of Scatchard and inhibition data by quantitative densitometry, one section was mounted per slide. For regional localization by quantitative densitometry, four consecutive sections at 500- $\mu$ In intervals were mounted, two per slide for total and nonspecific binding determinations.

Binding procedures. Slides were warmed to room temperature, and preincubated for $10 \mathrm{~min}$ in slide jars filled with $25^{\circ} \mathrm{C}$ buffer $(50 \mathrm{~mm}$ Tris- $\mathrm{HCl} / 5 \mathrm{mM} \mathrm{MgCl}_{2} / 0.2 \%$ bovine serum albumin, $\left.\mathrm{pH} 7.4\right)$. After preincubation, sections were immediately chilled to $4^{\circ} \mathrm{C}$, and allowed to air dry. Once dry, slides were incubated with $300 \mu \mathrm{l}$ of ice-cold buffer containing $20 \mu \mathrm{M}$ Bacitracin and nanomolar concentrations of $\left[{ }^{3} \mathrm{H}\right]$ MeTRH. This volume was sufficient to cover thoroughly both sections on a slide. Concentrations of $\left[{ }^{3} \mathrm{H}\right] \mathrm{MeTRH}$ used were $10 \mathrm{nM}$ for regional localization and from 0.3 to $22.9 \mathrm{nM}$ for Scatchard analysis. For inhibition and kinetic analyses, a 2 nM solution was used. Nine concentrations of TRH analogs, ranging over 5 orders of magnitude, were sometimes included in the incubation for inhibition analysis. Nonspecific binding was defined as the binding of $\left[{ }^{3} \mathrm{H}\right] \mathrm{MeTRH}$ in the presence of $10 \mu \mathrm{M}$ TRH. At $10 \mathrm{nM}\left[{ }^{3} \mathrm{H}\right] \mathrm{MeTRH}$, specific binding was 80 to $90 \%$ of total binding ( 1500 to $2000 \mathrm{cpm}$ ).

The sections were incubated at $4^{\circ} \mathrm{C}$ for $2 \mathrm{hr}$. After incubation, the slides were washed with ice-cold buffer four times for $30 \mathrm{sec}$ each. Preliminary experiments established that fewer washes after incubation resulted in a greater proportion of nonspecific binding (40 to 60\% of total binding). For scintillation counting, the sections were wiped off the slides with Whatman glass fiber filter discs, placed in vials with $5 \mathrm{ml}$ of Liquiscint (National Diagnostics, Somerville, NJ), and counted at $35 \%$ efficiency. For autoradiography, the slides were dipped in icecold distilled water to remove buffer salts and then rapidly dried on a 60 to $70^{\circ} \mathrm{C}$ slide drier.

Kinetic analysis. To study the rate of $\left[{ }^{3} \mathrm{H}\right] \mathrm{MeTRH}$ binding, sections were labeled for varying lengths of time up to $4 \mathrm{hr}$. The rate of dissociation was examined by incubating for $2 \mathrm{hr}$, and then plunging slides into ice-cold buffer with $10 \mu \mathrm{M}$ TRH (to prevent reassociation of dissociated radioligand) for time intervals up to $4 \mathrm{hr}$. After labeling or labeling and dissociation, sections were washed four times and wiped off for scintillation counting as described above.

Quantitative densitometry. Quantitative autoradiograms of $\left[{ }^{3} \mathrm{H}\right]$ Me'TRH binding was performed as described previously (Rainbow et al., 1982). Slides were affixed to cardboard Kodak x-ray exposure holders, and LKB Ultrofilm (LKB, Inc., Gaithersburg, MD) was apposed to the slides. Film cassettes were shelved and weighted to ensure steady, uniform apposition of film and tissue. After 2 months of exposure at room temperature, the LKB film was developed in Kodak GBX developer for $3 \mathrm{~min}$ followed by $6 \mathrm{~min}$ in Kodak rapid fixer.

Densitometric analysis of $\left.{ }^{3} \mathrm{II}\right] \mathrm{MeTRII}$ binding was carried out according to methods described previously (Unnerstall et al., 1982; Rainbow et al., 1982; Rainbow et al., 1984). Slide-mounted autoradiograms were magnified 10 times and the image was maneuvered over a photocell $100 \mu \mathrm{m}$ in diameter. This photocell was connected to a microcomputer capable of converting density values into femtomoles $/ \mathrm{mg}$ of protein using tritium film standards prepared from brain mash mixed with known quantities of $\left.{ }^{3} \mathrm{H}\right]$ leucine (Unnerstall et al., 1982; Rainbow et al., 1984). These standards are calibrated for the tritium content in gray matter structures (Rainbow et al., 1984). Therefore, we have analyzed only grey matter structures to avoid the problem of tritium quench by white matter (Alexander et al., 1981). Values for total and nonspecific binding of $\left[{ }^{3} \mathrm{H}\right] \mathrm{MeTRH}$ were obtained for each region by averaging four to eight readings for each brain structure on an individual autoradiogram. Equal numbers of readings were taken bilaterally and averaged together.

\section{Results}

Scatchard analysis of $\left[{ }^{3} \mathrm{H}\right] \mathrm{MeTRH}$ binding to frozen brain sections by liquid scintillation counting. Experiments showed specific $\left[{ }^{3} \mathrm{H}\right] \mathrm{MeTRH}$ binding to sections through rat amygdala began to saturate at ligand concentrations greater than $10 \mathrm{nM}$. Linear Scatchard curves were generated with seven ligand concentrations ranging from 0.3 to $22.9 \mathrm{nM}$. We obtained a $K_{\mathrm{d}}$ of $5.80 \pm 0.64 \mathrm{nM}$, which compares well with previous reports (Taylor and Burt, 1981; Simasko and Horita, 1982; Thompson et al., 1981; Burt and Ajah, 1984). The $B_{\max }$ was $43.92 \pm 4.71$ $\mathrm{fmol} / \mathrm{mg}$ of protein. Our data also provide no evidence of cooperativity or multiple binding sites, with a Hill coefficient $(1.16 \pm 0.09)$ not significantly different from $1.0(t(3)=1.778$; $p=\mathrm{NS})$.

Kinetic analysis of $\left[{ }^{3} \mathrm{H}\right] \mathrm{MeTRH}$ binding to frozen brain sections by liquid scintillation counting. Examination of the time course of $\left[{ }^{3} \mathrm{H}\right] \mathrm{MeTRH}$ binding revealed a rate constant $\left(k_{-1}\right)$ of $0.00576 \pm 0.00027 \mathrm{~min}^{-1}$ for the dissociation reaction. For the association reaction, $k_{\text {obs }}$ was determined to be $0.00802 \pm$ $0.00114 \mathrm{~min}^{-1}$, and equilibrium was reached at approximately $90 \mathrm{~min}$. The calculated $K_{\mathrm{d}}$ of $5.10 \mathrm{~nm}$ provided close agreement with the results of our Scatchard analysis of $\left[{ }^{3} \mathrm{H}\right] \mathrm{MeTRH}$ binding to rat brain slices. The calculated $K_{\mathrm{d}}$ also closely agree with Simasko and Horita (1982) and Taylor and Burt (1981), who reported calculated $K_{\mathrm{d}}$ values of 1.6 and $5.4 \mathrm{nM}$, respectively.

Inhibition analysis of $\left[{ }^{3} \mathrm{H}\right] \mathrm{MeTRH}$ binding to frozen brain sections by liquid scintillation counting. TRH analogs were added to the incubation fluid to determine their ability to inhibit the binding of $\left[{ }^{3} \mathrm{H}\right] \mathrm{MeTRH}$. The data are presented in Table I. MeTRH, TRH, and TRH-Gly-NH $\mathrm{NH}_{2}$ all inhibited the binding of $\left[{ }^{3} \mathrm{H}\right] \mathrm{MeTRH}$ by $50 \%$ with nanomolar potency. TRH$\mathrm{OH}$ and Glu-His-Pro- $\mathrm{NH}_{2}$ were only moderately effective, with potencies in the micromolar range. Pro- $\mathrm{NH}_{2}$ and cyclo(-HisPro-) were the least effective compounds at inhibiting the binding of $\left[{ }^{3} \mathrm{H}\right] \mathrm{MeTRH}$ with millimolar $\mathrm{IC}_{\overline{50}}$ values. The rank order potencies of these compounds correlate closely with those seen in brain homogenates from sheep (Taylor and Burt, 1981; Spearman rank order correlation coefficient $r_{\mathrm{s}}=0.96 ; p=0.02$ ).

Densitometric characterization of $\left[{ }^{3} \mathrm{H}\right] \mathrm{MeTRH}$ binding to frozen brain sections. Frozen brain sections were incubated with varying concentrations of $\left[{ }^{3} \mathrm{H}\right] \mathrm{Me} \mathrm{TRH}$, or incubated with $2 \mathrm{nM}$ 
TABLE I

Relative potency of TRH analogs in displacing $\left[{ }^{3} \mathrm{H}\right] \mathrm{MeTRH}$ binding to rat brain sections

Several concentrations of TRH analogs were included in the incubation with $\left.2 \mathrm{nM} \mathrm{[}{ }^{3} \mathrm{H}\right] \mathrm{MeTRH}$. Binding was assayed by liquid scintillation counting as described in the text. Values are means and standard errors for three to seven experiments.

\begin{tabular}{lr}
\hline \multicolumn{1}{c}{ Compound } & \multicolumn{1}{c}{$\mathrm{IC}_{50}$ (Mean $\left.\pm \mathrm{SEM}\right)$} \\
\hline MeTRH & $2.10 \pm 1.30 \mathrm{nM}$ \\
TRH & $41.40 \pm 16.00 \mathrm{nM}$ \\
TRH-Gly-NH & $143.90 \pm 26.70 \mathrm{nM}$ \\
TRH-OH & $1.99 \pm 0.54 \mu \mathrm{M}$ \\
Glu-His-Pro- $\mathrm{NH}_{2}$ & $3.03 \pm 1.44 \mu \mathrm{M}$ \\
cyclo(-His-Pro-) & $1.11 \pm 0.57 \mathrm{mM}$ \\
Pro- $\mathrm{NH}_{2}$ & $13.87 \pm 4.83 \mathrm{mM}$ \\
\hline
\end{tabular}

$\left.{ }^{3} \mathrm{H}\right] \mathrm{MeTRH}$ in the presence of varying concentrations of $\mathrm{TRH}$ or MeTRH. Autoradiograms were thus generated and quantified by densitometry for Scatchard and inhibition analyses. The data for five representative limbic nuclei are presented in Table II. The $K_{\mathrm{d}}$ and $\mathrm{IC}_{50}$ values for each nucleus corresponded well to the values obtained by liquid scintillation counting of sections labeled with $\left[{ }^{3} \mathrm{H}\right] \mathrm{MeTRH}$ (Table I). Each $B_{\max }$ was 5 to 10 times greater than the $B_{\max }$ determined by Scatchard analysis of $\left[{ }^{3} \mathrm{H}\right] \mathrm{MeTRH}$ binding to brain slices. This reflected dilution of TRH receptors in Scatchard analysis of pooled brain regions seen with brain slices containing heterogeneous $\mathrm{TRH}$ receptor concentrations. The rank orders of TRH receptor concentrations in these nuclei determined by densitometric Scatchard analysis and densitometric mapping studies were identical (see Table III).

Densitometric quantification of regional binding. We observed marked heterogeneity in the pattern of $\left[{ }^{3} \mathrm{H}\right] \mathrm{MeTRH}$ binding to TRH receptors (Fig. 1; Tables III and IV). Receptors were discretely localized throughout the CNS, with highest concentrations present in rhinencephalic structures. Areas of the olfactory apparatus, the entire amygdala and adjacent regions, and discrete sites within the hippocampus and septum contained moderately high (100 to $200 \mathrm{fmol} / \mathrm{mg}$ of protein) to very high (200 to $400 \mathrm{fmol} / \mathrm{mg}$ of protein) concentrations of TRH receptors. Moderate densities (50 to $100 \mathrm{fmol} / \mathrm{mg}$ of protein) of $\mathrm{TRH}$ receptors were observed in the brainstem, spinal cord, hypothalamus, and thalamus. Finally, the basal ganglia, neocortex, and cerebellum possessed low levels (less than $50 \mathrm{fmol} /$ $\mathrm{mg}$ of protein) of TRH receptors. Throughout the CNS, nonspecific binding did not exceed film background measured by densitometry, and was visually equivalent to film background. Although regions may appear homogeneously gray (e.g., cerebellum in Fig. $1 J$ ), they nonetheless contain specific TRH receptors, albeit in low concentrations.

Within the rhinencephalon, the accessory olfactory bulb contained the highest concentration of TRH receptors (363.1 $\pm 18.6 \mathrm{fmol} / \mathrm{mg}$ of protein) seen on the neuraxis. The granular layer of the accessory olfactory bulb also possessed a very high density of TRH receptors, exceeding $200 \mathrm{fmol} / \mathrm{mg}$ of protein.

Caudally within the rhinencephalon, all the nuclei of the amygdala contained high concentrations of TRH receptors. Labeling by $\left[{ }^{3} \mathrm{H}\right] \mathrm{MeTRH}$ in the posterior cortical, lateral, medial, and basolateral nuclei was very high, whereas moderately high levels of $\mathrm{TRH}$ receptors were contained in the central and anterior cortical nuclei. The adjacent endopiriform nucleus contained a moderately high density of TRH receptors (110.7 $\pm 10.5 \mathrm{fmol} / \mathrm{mg}$ of protein), and the amygdalohippocampal area was very heavily labeled with TRH receptors $(250.4 \pm 74.6$ $\mathrm{fmol} / \mathrm{mg}$ of protein).

In the hippocampus, very high densities of $\mathrm{TRH}$ receptors were concentrated in the ventral regions of the subiculum and the dentate gyrus. However, only low concentrations of TRH receptors, never exceeding $50 \mathrm{fmol} / \mathrm{mg}$ of protein, were seen in the dorsal subfields of the hippocampus. This clear dorsal/ ventral variation in the hippocampus was manifested by a $10-$ fold greater concentration of TRH receptors in the ventral dentate gyrus than in the dorsal dentate gyrus.

Rhinencephalic cortical structures, overlying the amygdala and hippocampus, possessed moderately high levels of TRH receptors. The concentration within entorhinal cortex exceeded $100 \mathrm{fmol} / \mathrm{mg}$ of protein. In the cortex delineating the rhinal fissure, corresponding to area no. 13 in the scheme of Krieg (1946), the TRH receptor concentration was over $180 \mathrm{fmol} / \mathrm{mg}$ of protein. This large region of cortex was concentrated in TRH receptors, extending from levels 13 to 30 in the atlas of Paxinos and Watson (1982). However, the discrete pattern of $\left[{ }^{3} \mathrm{H}\right]$ MeTRH binding was very consistent, the points of origin and termination of the labeling pattern each varying no more than $500-\mu \mathrm{m}$ between rats. In addition, no significant anteroposterior variation in TRH receptor concentrations through the rhinal cortex was noted.

A discrete pattern of labeling was noted within the septal area of the rhinencephalon. The bed nucleus of the stria terminalis, the septohypothalamic nucleus, and the islands of Calleja Major all contained high concentrations of TRH receptors, as did both the vertical and the horizontal limbs of the diagonal band of Broca. The taenia tecta, medial septum, septohippocampal nucleus, and columns of the fornix each possessed more moderate densities of TRH receptors. Low levels of TRH receptors were found in the lateral septum and the olfactory tubercle.

In contrast to the rhinencephalon, the concentration of TRH receptors in the mesencephalon and the rhombencephalon were moderate, generally ranging from 50 to $100 \mathrm{fmol} / \mathrm{mg}$ of protein. Within the mesencephalon, the interpeduncular nucleus and the inferior colliculus contained concentrations of TRH receptors approaching $70 \mathrm{fmol} / \mathrm{mg}$ of protein. Exceptions to the general pattern of moderate $\mathrm{TRH}$ receptor concentrations within the mesencephalon included the superior colliculus, with

TABLE II

Densitometric characterization of $\left[{ }^{3} \mathrm{H}\right] \mathrm{MeTRH}$ binding in representative limbic nuclei of the rat

For Scatchard analysis, several concentrations of $\left[{ }^{3} \mathrm{H}\right] \mathrm{MeTRH}$ were included in the incubation. For inhibition analysis, several concentrations of TRH or MeTRH were included in the incubation with $2 \mathrm{nM}\left[{ }^{3} \mathrm{H}\right] \mathrm{MeTRH}$. Sections were then dried and apposed to LKB Ultrofilm for 2 months to generate autoradiograms, and binding in specific nuclei was quantified by densitometry as described in the text. Nonspecific binding was defined as binding in the presence of $10 \mu \mathrm{M}$ TRH. Values are means and standard errors of three or four experiments.

\begin{tabular}{|c|c|c|c|c|}
\hline Structure & $K_{\mathrm{d}}$ & $B_{\max }$ & TRH IC 50 & MeTRH IC 50 \\
\hline & $n_{M}$ & $\mathrm{fmol} / \mathrm{mg}$ protein & $n_{M}$ & $n_{\mathrm{m}}$ \\
\hline Medial nucleus, amygdala & $3.49 \pm 0.68$ & $493.9 \pm 80.8$ & $19.8 \pm 6.7$ & $1.0 \pm 0.5$ \\
\hline Basolateral mucleus, amygdala & $2.78 \pm 0.38$ & $373.1 \pm 79.8$ & $25.7 \pm 11.5$ & $1.3 \pm 0.5$ \\
\hline Central nucleus, amygdala & $5.17 \pm 2.18$ & $333.4 \pm 67.6$ & $40.7 \pm 25.0$ & $1.7 \pm 0.7$ \\
\hline Endopiriform nucleus & $2.68 \pm 0.40$ & $316.0 \pm 59.2$ & $10.7 \pm 3.4$ & $0.8 \pm 0.1$ \\
\hline Anterior cortical nucleus, amygdala & $2.84 \pm 0.58$ & $250.4 \pm 40.5$ & $24.9 \pm 16.3$ & $0.5 \pm 0.2$ \\
\hline
\end{tabular}


TABLE III

Concentration of TRH receptors in rat brain determined by quantitative autoradiography

Frozen $32-\mu \mathrm{m}$ thick brain sections were labeled as described in the text with $10 \mathrm{nM}\left[{ }^{3} \mathrm{H}\right] \mathrm{MeTRH}$, and apposed against LKB Ultrofilm for 2 months to generate autoradiograms. Brain sections were taken at $500-\mu \mathrm{m}$ intervals corresponding to coronal levels of the atlas of Paxinos and Watson (1982). Serially cut sections at each level were used for determination of total and nonspecific binding. Four to eight readings were taken for each brain structure on an individual autoradiogram. Densitometric readings were converted into molar levels of $\left[{ }^{3} \mathrm{H}\right] \mathrm{MeTRH}$ binding by reference to a tritium brain-mash standard curve (Unnerstall et al., 1982; Rainbow et al., 1984). Nonspecific binding, defined as binding in the presence of $10 \mu \mathrm{M} \mathrm{TRH}$, did not exceed film background. All layers of the cerebral cortex were labeled homogeneously, as were all the nuclei and lamina of the cerebellum. Values are means and standard errors of femtomoles of $\left[{ }^{3} \mathrm{H}\right] \mathrm{MeTRH}$ specifically bound per $\mathrm{mg}$ of protein, from readings taken from four rats.

\begin{tabular}{|c|c|}
\hline Structure & Mean $\pm \mathrm{SEM}$ \\
\hline \multicolumn{2}{|l|}{ Olfactory apparatus } \\
\hline Olfactory bulb & $22.2 \pm 7.3$ \\
\hline Granular layer, accessory olfactory bulb & $262.5 \pm 47.5$ \\
\hline Accessory bulb & $363.1 \pm 18.6$ \\
\hline \multicolumn{2}{|l|}{ Basal ganglia } \\
\hline Accumbens nucleus & $21.4 \pm 8.4$ \\
\hline Caudate putamen & $17.7 \pm 10.2$ \\
\hline \multicolumn{2}{|l|}{ Limbic forebrain } \\
\hline Taenia tecta & $98.7 \pm 17.5$ \\
\hline Islands of Calleja Major & $131.0 \pm 21.8$ \\
\hline Olfactory tubercle & $3.9 \pm 1.5$ \\
\hline Medial septum & $70.2 \pm 5.7$ \\
\hline Lateral septum, intermediate & $38.4 \pm 18.0$ \\
\hline Lateral septum, dorsal & $14.3 \pm 4.6$ \\
\hline Lateral septum, ventral & $35.5 \pm 18.1$ \\
\hline Diagonal band of Broca, vertical limb & $134.2 \pm 13.2$ \\
\hline Diagonal band of Broca, horizontal limb & $107.1 \pm 16.5$ \\
\hline Bed nucleus of the stria terminalis & $161.7 \pm 15.9$ \\
\hline Septohippocampal nucleus & $57.4 \pm 9.0$ \\
\hline Septohypothalamic nucleus & $108.4 \pm 26.3$ \\
\hline Ventral palladium & $28.3 \pm 8.9$ \\
\hline Fornix & $56.9 \pm 19.5$ \\
\hline \multicolumn{2}{|l|}{ Cortex } \\
\hline Rhinal cortex & $182.7 \pm 10.6$ \\
\hline Frontal cortex & $26.4 \pm 3.7$ \\
\hline Primary olfactory cortex & $34.0 \pm 7.4$ \\
\hline Anterior cingulate cortex & $45.3 \pm 9.8$ \\
\hline Posterior cingulate cortex & $63.7 \pm 7.4$ \\
\hline Entorhinal cortex & $126.8 \pm 36.2$ \\
\hline \multicolumn{2}{|l|}{ Amygdala } \\
\hline Central nucleus & $137.7 \pm 18.6$ \\
\hline Medial nucleus & $215.3 \pm 53.9$ \\
\hline Lateral nucleus & $231.0 \pm 61.6$ \\
\hline Basolateral nucleus & $207.4 \pm 36.1$ \\
\hline Anterior cortical nucleus & $129.3 \pm 24.5$ \\
\hline Posterior cortical nucleus & $243.8 \pm 22.8$ \\
\hline Endopiriform nucleus & $110.7 \pm 10.5$ \\
\hline Amygdalohippocampal area & $250.4 \pm 74.6$ \\
\hline \multicolumn{2}{|l|}{ Thalamus } \\
\hline Paraventricular nucleus & $135.1 \pm 10.4$ \\
\hline Centromedial nucleus & $43.5 \pm 7.4$ \\
\hline Gelatinosus nucleus & $36.0 \pm 6.9$ \\
\hline Intermediodorsal nucleus & $51.9 \pm 8.7$ \\
\hline Reuniens & $77.0 \pm 13.0$ \\
\hline Lateral posterior nucleus & $32.3 \pm 8.3$ \\
\hline Habenular nuclei & $33.4 \pm 8.8$ \\
\hline
\end{tabular}

TABLE III-Continued

\begin{tabular}{|c|c|}
\hline Structure & Mean \pm SEM \\
\hline \multicolumn{2}{|l|}{ Hypothalamus } \\
\hline Lateral preoptic area & $79.2 \pm 19.2$ \\
\hline Medial preoptic area & $91.6 \pm 8.3$ \\
\hline Suprachiasmatic nucleus & $126.9 \pm 8.8$ \\
\hline Lateral hypothalamic area & $48.0 \pm 6.6$ \\
\hline Anterior hypothalamic area & $71.6 \pm 16.0$ \\
\hline Ventromedial nucleus & $78.4 \pm 17.1$ \\
\hline Paraventricular nucleus & $90.9 \pm 6.5$ \\
\hline Periventricular nucleus & $93.8 \pm 22.7$ \\
\hline Arcuate nucleus & $68.9 \pm 9.9$ \\
\hline Median eminence & $36.0 \pm 9.1$ \\
\hline Dorsomedial nucleus & $95.2 \pm 14.8$ \\
\hline Posterior nucleus & $106.2 \pm 16.4$ \\
\hline Zona incerta & $67.0 \pm 12.5$ \\
\hline Mammillary nuclei & $96.2 \pm 22.2$ \\
\hline Supramammillary nuclei & $94.6 \pm 14.4$ \\
\hline \multicolumn{2}{|l|}{ Hippocampus } \\
\hline \multicolumn{2}{|l|}{ Dorsal } \\
\hline CA1 & $25.7 \pm 4.3$ \\
\hline CA2 & $31.2 \pm 7.5$ \\
\hline CA3 & $25.0 \pm 8.0$ \\
\hline Dentale gyrus & $23.7 \pm 8.1$ \\
\hline \multicolumn{2}{|l|}{ Ventral } \\
\hline CA3 & $97.0 \pm 32.9$ \\
\hline CA4 & $28.5 \pm 3.6$ \\
\hline Dentate gyrus & $272.4 \pm 57.8$ \\
\hline Subiculum & $314.9 \pm 35.8$ \\
\hline \multicolumn{2}{|l|}{ Midbrain } \\
\hline Interpeduncular nucleus & $65.7 \pm 31.0$ \\
\hline Substantia nigra & $30.7 \pm 8.4$ \\
\hline Central gray & $75.6 \pm 13.5$ \\
\hline Superior colliculus & $125.8 \pm 21.9$ \\
\hline Inferior colliculus & $68.6 \pm 17.0$ \\
\hline \multicolumn{2}{|l|}{ Cranial nerve nuclei } \\
\hline Motor nucleus (5) & $55.6 \pm 7.9$ \\
\hline Principal sensory nucleus (5) & $56.8 \pm 12.3$ \\
\hline Spinal nucleus (5) & $30.0 \pm 6.9$ \\
\hline Facial nucleus (7) & $77.3 \pm 9.6$ \\
\hline Medial vestibular nucleus ( 8 ) & $90.0 \pm 22.9$ \\
\hline Lateral vestibular nucleus (8) & $40.7 \pm 3.5$ \\
\hline Superior vestibular nucleus ( 8 ) & $34.0 \pm 5.5$ \\
\hline Solitary nucleus and tract (10) & $108.0 \pm 4.3$ \\
\hline Dorsal motor nucleus (10) & $150.6 \pm 15.7$ \\
\hline Hypoglossal nucleus (12) & $140.6 \pm 14.5$ \\
\hline \multicolumn{2}{|l|}{ Brainstem } \\
\hline Paragigantocellular nucleus & $64.4 \pm 16.3$ \\
\hline Parvocellular reticular nucleus & $51.6 \pm 5.1$ \\
\hline Pontine caudal reticular nucleus & $50.2 \pm 16.5$ \\
\hline Lateral reticular nucleus & $62.9 \pm 9.7$ \\
\hline Medullary reticular nucleus & $39.8 \pm 11.4$ \\
\hline Superior olive & $46.4 \pm 16.1$ \\
\hline Inferior olive & $46.7 \pm 22.7$ \\
\hline Dorsal medial raphe & $64.6 \pm 6.3$ \\
\hline Locus ceruleus & $74.1 \pm 12.7$ \\
\hline Cerebellum & $14.5 \pm 4.1$ \\
\hline
\end{tabular}

a moderately high density of TRH receptors, and the interpeduncular nucleus, with a low density of TRH receptors. The central gray, moderately dense with TRH receptors $(75.6 \pm$ $13.5 \mathrm{fmol} / \mathrm{mg}$ of protein), possessed homogeneous labeling throughout the mesencephalon and extending into the pontine region of the rhombencephalon.

Moderate concentrations of TRH receptors were observed throughout the rhombencephalon. Several nuclei of the reticular formation, the dorsal medial raphe, and the locus ceruleus all contained TRH receptors in concentrations of 50 to $75 \mathrm{fmol} /$ 
A.

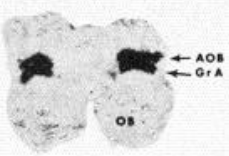

B.

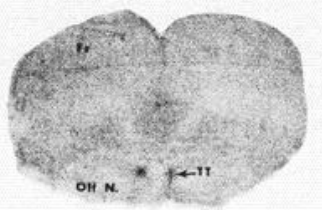

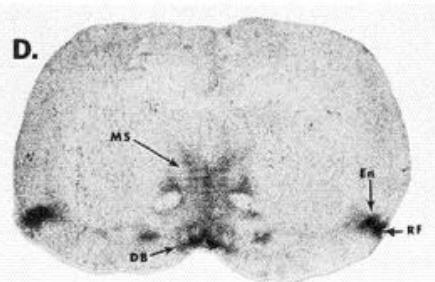
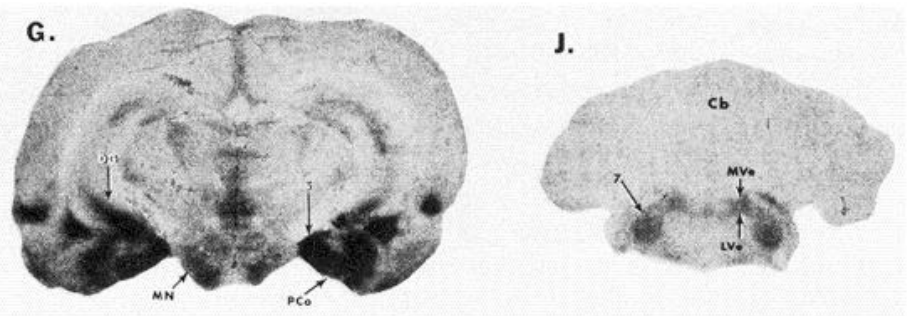

K.
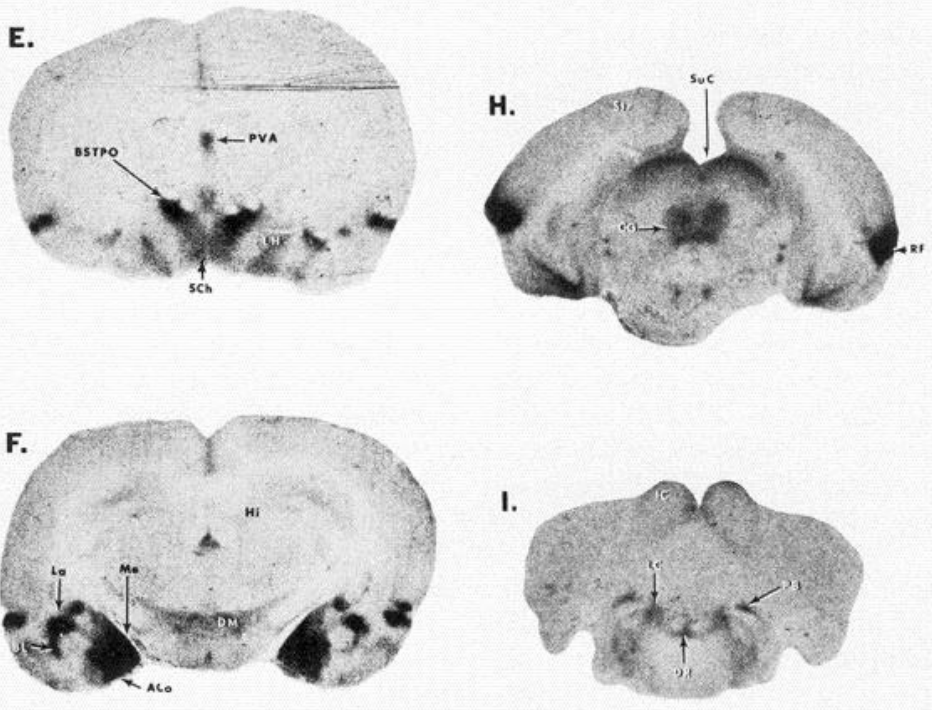

E.

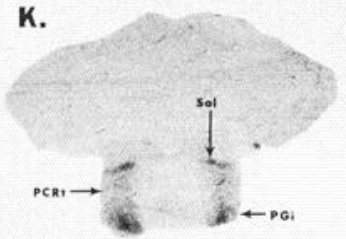

L.

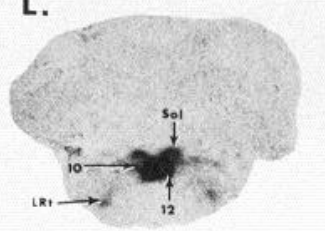

M.

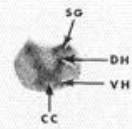

Figure 1. Distribution of TRH receptors in rat brain and spinal cord determined by quantitative autoradiography. Frozen $32-\mu \mathrm{m}$ thick sections of rat brain and spinal cord were labeled as described in the text with $10 \mathrm{nM}\left[{ }^{3} \mathrm{H}\right] \mathrm{MeTRH}$, and apposed to LKB Ultrofilm for 2 months to generate autoradiograms. The visual contribution of nonspecific binding was equivalent to the binding over white matter. Each of the frames $A$ to $M$ represents a coronal level from the atlas of Paxinos and Watson (1982). A, level 4: $A O B$, accessory olfactory bulb; $G r A$, granular layer of the accessory olfactory bulb; $O B$, olfactory bulb. $B$, level 7: $F r$, frontal cortex; $T T$, taenia tecta; $O l f N$., anterior olfactory nuclei. $C$, level $11: C P u$, caudate putamen; $T T$, taenia tecta; $I C j M$, islands of Calleja Major; $S H i$, septohippocampal nucleus. $D$, level 14: $M S$, medial septum; $D B$, diagonal band of Broca; $E n$, endopiriform nucleus; $R F$, rhinal cortex. $E$, level 17: $P V A$, paraventricular thalamic nucleus; $B S T P O$, preoptic bed nucleus of the stria terminalis; $L H$, lateral hypothalamus; $S C h$, suprachiasmatic nucleus. $F$, level $20: H i$, dorsal hippocampus; $D M$, dorsomedial hypothalamus; $M e$, medial nucleus, amygdala; $A C o$, anterior cortical nucleus, amygdala; $L a$, lateral nucleus, amygdala; $B L$, basolateral nucleus, amygdala. $G$, level 24: $D G$, ventral dentate gyrus; $S$, subiculum; $M N$, mammillary nuclei; $P C o$, posterior cortical nucleus. $H$, level $29: S u C$, superior colliculus; Str, striate cortex; $C G$, central gray; $R F$, rhinal cortex. $I$, level 33: $I C$, inferior colliculus; $L C$, locus ceruleus; $D R$, dorsal raphe; $P B$, parabrachial nucleus. $J$, level 35: $C b$, cerebellum; 7, facial nucleus; $M V e$, medial vestibular nucleus; $L V e$, lateral vestibular nucleus. $K$, level 38: Sol, solitary nucleus and tract; PCRt, parvocellular reticular nucleus; PGi, paragigantocellular reticular nucleus. $L$, level 41: Sol, solitary nucleus and tract; 12 , hypoglossal nucleus; 10 , dorsal motor nucleus; $L R t$, lateral reticular nucleus. $M$, level $68: S G$, substantia gelatinosa; $D H$, dorsal horn; $V H$, ventral horn; $C C$, central canal.

\section{TABLE IV}

Concentration of TRH receptors in rat spinal cord

Frozen $32-\mu \mathrm{m}$ thick spinal cord sections were labeled as described in the text with $10 \mathrm{nM}\left[{ }^{3} \mathrm{H}\right] \mathrm{MeTRH}$, and apposed against LKB Ultrofilm for 2 months to generate autoradiograms. Spinal cord sections were taken from cervical, thoracic, lumbar, and sacral levels. Serially cut sections at each level were used for determination of total and nonspecific binding. Four to eight readings were taken for each spinal cord structure on an individual autoradiogram. Values are means and standard errors of femtomoles of $\left[{ }^{3} \mathrm{H}\right] \mathrm{MeTRH}$ specifically bound per mg of protein, from readings taken from four to seven rats.

\begin{tabular}{|c|c|c|c|c|c|}
\hline Level & $\begin{array}{l}\text { Substantia } \\
\text { Gelatinosa }\end{array}$ & $\begin{array}{c}\text { Dorsal } \\
\text { Gray }\end{array}$ & $\begin{array}{l}\text { Ventral } \\
\text { Gray }\end{array}$ & $\begin{array}{c}\text { Central } \\
\text { Canal }\end{array}$ & $\begin{array}{l}\text { Intermediolateral } \\
\text { Column }\end{array}$ \\
\hline Cervical & $106.2 \pm 9.0$ & $55.5 \pm 6.1$ & $71.9 \pm 3.9$ & $84.6 \pm 10.1$ & \\
\hline Thoracic & $92.5 \pm 18.6$ & $48.8 \pm 9.8$ & $63.1 \pm 9.6$ & $82.8 \pm 13.1$ & $68.5 \pm 13.5$ \\
\hline Lumbar & $109.3 \pm 4.7$ & $62.4 \pm 3.6$ & $56.5 \pm 3.9$ & $88.9 \pm 6.4$ & \\
\hline Sacral & $107.9 \pm 20.0$ & $63.0 \pm 11.3$ & $61.2 \pm 10.1$ & $86.1 \pm 7.7$ & \\
\hline
\end{tabular}

mg of protein. The cranial nerve nuclei, however, displayed a highly discrete distribution, with TRH receptor concentrations appearing denser in more dorsal nuclei. The motor and principal sensory nuclei of the trigeminal nerve contained about 55 $\mathrm{fmol} / \mathrm{mg}$ of protein of TRH receptors, while the spinal trigeminal nucleus contained little more than half that amount $(30.0$ $\pm 6.9 \mathrm{fmol} / \mathrm{mg}$ of protein). The lateral and superior vestibular nuclei possessed less than half the density of TRH receptors seen in the medial vestibular nucleus, which possessed $90 \mathrm{fmol} /$ mg of protein of TRH receptors. Finally, the dorsal motor nucleus of the vagus and the hypoglossal nucleus, the most dorsal of the cranial nerve nuclei, as well as the solitary tract and nucleus, all contained over $100 \mathrm{fmol} / \mathrm{mg}$ of protein of TRH receptors.

In contrast to the cranial nerve nuclei, no rostrocaudal variation was seen in the moderate levels of TRH receptors present 
throughout the length of the spinal cord (Fig. 1; Table 4). The TRH receptor concentration in the substantia gelatinosa $(98.0$ $\pm 9.5 \mathrm{fmol} / \mathrm{mg}$ of protein) was the highest of any spinal cord region. The intermediolateral column of the thoracic cord contained a moderate density of TRH receptors. The dorsal and ventral horns and the central canal possessed moderate densities of TRH receptors ranging from 50 to $80 \mathrm{fmol} / \mathrm{mg}$ of protein.

The diencephalon was also moderately dense in TRH receptors. Within the hypothalamus, TRH receptor concentrations ranged from 50 to $100 \mathrm{fmol} / \mathrm{mg}$ of protein in many nuclei, including the periventricular, paraventricular, arcuate, ventromedial, and dorsomedial nuclei. Regions such as the lateral and medial preoptic areas and the lateral hypothalamus also contained moderate densities of TRH receptors. However, the posterior and the suprachiasmatic nuclei contained high concentrations of TRH receptors, exceeding $100 \mathrm{fmol} / \mathrm{mg}$ of prolein each. The median eminence, containing only $36 \mathrm{fmol} / \mathrm{mg}$ of protein, was also an exception to the moderate levels of TRH receptors seen in the hypothalamus.

The thalamic diencephalon contained moderate to low levels of TRH receptors. Within the thalamus, we observed low levels of TRH receptors (habenular, centromedial, gelatinosus, and lateral posterior nuclei) and moderate levels of TRH receptors (intermediodorsal and reuniens nuclei). The single thalamic structure containing a high concentration of TRH receptors was the paraventricular nucleus $(135.1 \pm 10.4 \mathrm{fmol} / \mathrm{mg}$ of protein).

In more recently evolved regions of brain, including neocortex and basal ganglia, we observed low levels of TRH receptors. This labeling, though of low magnitude, clearly exceeded background binding levels. The accumbens nucleus, caudate putamen, and ventral palladium each possessed less than $30 \mathrm{fmol} /$ $\mathrm{mg}$ of protein. Neocortical regions, such as striate and cingulate cortex, also possessed low levels of TRH receptors, with all cortical layers homogeneously labeled.

$\left[{ }^{3} \mathrm{H}\right] \mathrm{MeTRH}$ labeled the cerebellum homogeneously and in low levels $(14.5 \pm 4.1 \mathrm{fmol} / \mathrm{mg}$ of protein). No differences in regions of cerebellar cortex or nuclei were detectable.

\section{Discussion}

We have shown, by quantitative autoradiography, the distribution of TRH receptors throughout the rat CNS (Fig. 1; Tables 3 and 4). Highest concentrations of TRH receptors were localized to the rhinencephalon, including the accessory olfactory bulb, ventral hippocampus, and amygdala. Moderate TRH receptor densities were found in the diencephalon, rhombencephalon, and spinal cord. Recently evolved regions of brain, such as neocortex and basal ganglia, contained low levels of TRH receptors.

Our results agreed with the localization of TRH receptors described by membrane homogenate techniques of other groups (Burt and Snyder, 1975; Simasko and Horita, 1982; Taylor and Burt, 1982). All groups showed high labeling in the amygdala, hypothalamus, and rhinal cortex, with more moderate labeling in diencephalic, mesencephalic, and rhombencephalic structures. All found little receptor labeling in the neocortex, basal ganglia, and cerebellum. Few important differences were observed between studies, and the differences noted were probably due to variations in technique. For example, Taylor and Burt (1982) reported relatively high concentrations in the nucleus accumbens, which we found to be extremely low in TRH receptors. However, the gross dissection technique used to obtain nucleus accumbens tissue may have included regions of the taenia tecta, islands of Calleja Major, bed nucleus of the stria terminalis, diagonal band of Broca, or medial septum which contained significant concentrations of TRH receptors.

The distribution of TRH receptors in brain regions observed in the present study differed substantially from the pattern of localization of TRH seen in previous reports (Brownstein et al., 1974; Eskay et al., 1983; Kubek et al., 1983). For example, very high levels of TRH receptors are found in the nuclei of the amygdala and ventral hippocampus, regions reported to contain low concentrations of endogenous TRH. Conversely, high TRH concentrations have been observed in median eminence and olfactory bulb, yet these areas contain low levels of TRH receptors. However, only limited information is available on the quantitative distribution of TRH in nuclei and subregions of rat brain. Moreover, a direct comparison of the regional distributions of TRH and TRH receptors should optimally be carried out in the same study. If such a comparison substantiated the lack of correspondence between TRH and its receptors, it would represent another example of the inconsistent relationship previously reported for the distributions of many other neurotransmitters and neuromodulators and their respective receptors (Kuhar, 1981).

While there is a lack of correspondence between the distribution of TRH and its receptors, a good correspondence exists betwein the distribution of TRH receptors and the effects of exogenously applied TRH. Microiontophoretically applied TRH lowers neuronal firing rates in the preoptic area, the septum, and the hypothalamus, but not in the cerebral cortex (Dyer and Dyball, 1974; Renaud and Martin, 1975; Renaud et al., 1975; Winokur and Beckman, 1978). The medial and lateral preoptic areas, numerous structures within the septal area, and all the hypothalamic nuclei contain greater TRH receptor concentrations than the frontal cortex. In microinjection studies, regions which show the greatest response to TRH are areas containing moderate to high densities of TRH receptors. Wei et al. (1975) elicited shaking behaviors after microinjecting $\mathrm{TRH}$ into the central gray, medial thalamus, medial preoptic area, and the medial hypothalamus. Boschi and Rips (1981) elicited a hyperthermia after microinjection of TRH into the diagonal band of Broca, the medial and lateral preoptic areas, and the anterior and lateral hypothalamus. Kalivas and Horita (1979) reversed pentobarbital narcosis with microinjection of TRH into the septum, medial preoptic area, medial thalamus, locus ceruleus, and mesencephalic periventricular gray. Additionally, Kalivas and Horita (1980) demonstrated the diagonal band of Broca and the medial septal nucleus to be more sensitive to the effect of TRH in reversing pentobarbital narcosis than the lateral septal nuclei. These regions of physiologic sensitivity to TRH administration correspond closely to the relative distribution of $T R H$ receptors in the septum.

Other studies indicate possible effects of exogenously applied TRH in regions where we find low levels of TRH receptors. Miyamota and Nagawa (1977) and Heal and Green (1979) microinjected TRH into the nucleus accumbens of rats to elicit locomotion, along with several other associated behaviors. We, unlike Taylor and Burt (1982), failed to see significant levels of TRH receptors in the nucleus accumbens. Rather, the effect may be secondary to local spread of $\mathrm{TRH}$ to immediately adjacent regions, such as the diagonal band of Broca and the islands of Calleja Major, that were highly concentrated with TRH receptors. Stanton et al. (1980) microinjected TRH into the dorsal hippocampus of the ground squirrel, producing arousal from hibernation, and elevation of body temperature and metabolic rate. However, greater densities of TRH receptors were seen ventrally within the hippocampus. It is possible that regional differences in TRH receptor density in the hippocampus existed as a function of species differences.

While iontophoretic and microinjection studies with TRH suggest that some TRH receptors are postsynaptic on neurons, it is conceivable that some TRH receptors are presynaptic. For example, the distribution of TRH receptors in the rat CNS resembled the distribution of norepinephrine terminals. The accessory olfactory bulb (Fallon and Moore, 1978), the bed 
nucleus of the stria terminalis and diagonal band of Broca (Lindvall and Stenevi, 1978; Moore, 1978), the paraventricular thalamic nucleus (Lindvall et al., 1974), and the amygdala (Fallon et al., 1978) all contain high levels of norepinephrine terminals. These regions also contain high to very high levels of TRH receptors (Table 3). The locus ceruleus contains the cell bodies whose noradrenergic fibers project throughout the CNS (Carlsson et al., 1962; Fuxe, 1965; Swanson and Hartman, 1975). The locus ceruleus also possessed a moderate density of TRH receptors. Other interactions between TRH and norepinephrine have been demonstrated in TRH microiontophoresis studies (Winokur and Beckman, 1978), norepinephrine turnover studies (Horst and Spirt, 1974; Keller et al., 1974), and 6hydroxydopamine lesion studies (Winokur et al., 1978). These data suggest that some $\mathrm{TRH}$ receptors are presynaptic on norepinephrine terminals.

Just as the cellular localization of TRH receptors remains unknown, so does the biologic function of these receptors. However, on the hasis of our results it is now possible to propose functions for TRH receptors in specific brain regions. For example, the suprachiasmatic nucleus contains a moderately high concentration of TRH receptors $(126.9 \pm 8.8 \mathrm{fmol} / \mathrm{mg}$ of protein). This nucleus also plays a role in the cyclic levels of several neurotransmitter receptors (Kafka et al., 1983). TRH levels within the rat amygdala (Collu et al., 1977), mediobasal hypothalamus (Mannisto et al., 1978; Kerdelhue et al., 1981), preoptic area (Kerdelhue et al., 1981), and retina (Schaeffer et al., 1977) have been shown to undergo circadian variation. Additionally, TRH levels in the preoptic area and olfactory bulb of the ground squirrel demonstrated seasonal variation (Stanton et al., 1982). These data may suggest a role for the suprachiasmatic nucleus in regulating the cyclicity of TRH concentrations and possibly TRH receptor concentrations in the brain.

While we can propose functions for some of the receptors for TRH localized by quantitative autoradiography, the significance of these receptors in most brain regions remains unknown. TRH occurs in extrahypothalamic neural tissues from a wide variety of lower vertebrates (Jackson and Reichlin, 1974b; Taurog et al., 1974; Stanton et al., 1982). The observation that TRH receptors are primarily localized in phylogenetically ancient brain regions may suggest that TRH and TRH receptors function in the regulation of basic biologic processes within the central nervous system.

\section{References}

Alexander, G. M., R. J. Schwartzman, R. D. Bell, and A. Renthal (1981) Quantitative measurement of local cerebral metabolic rate for glucose utilizing tritiated 2-deoxyglucose. Brain Res. 223: 59-67.

Bassiri, R. M., and R. D. Utiger (1972) The preparation and specificity of antibody to thyrotropin releasing hormone. Endocrinology 90 . $722-727$.

Boler, R. M., F. Enzman, K. Folkers, C. Y. Bowers, and A. V. Schally (1969) The identity of chemical and hormonal properties of the thyrotropin releasing hormone and pyroglutamyl-histidyl-proline amide. Biochem. Biophys. Res. Commun. 37: 705-710.

Boschi, G., and R. Rips (1981) Effects of thyrotropin releasing hormone injections into different loci of rat brain on core temperature. Neurosci. Lett. 23: 93-98.

Brownstein, M. J., M. Palkovits, J. M. Saavedra, R. M. Bassiri, and R. D. Utiger (1974) Thyrotropin releasing hormone in specific nuclei of rat brain. Science 185: 267-269.

Burgus, R., T. F. Dunn, D. Desiderio, and R. G. Guillemin (1969) Structure moleculaire du facteur hypothalamique hypophysiotrope TRH d'origine ovine: mise en evidence pour spectrometrie de masse

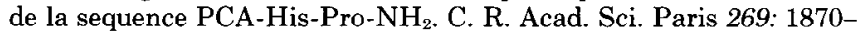
1873.

Burt, D. R., and M. Ajah (1984) TRH receptors in fish. Gen. Comp. Endocrinol. 53: 135-142.

Burt, D. R., and S. H. Snyder (1975) Thyrotropin releasing hormone
(TRH): apparent receptor binding in rat brain membranes. Brain Res. 93: 309-328.

Burt, D. R., and R. L. Taylor (1980) Binding sites for thyrotropin releasing hormone in sheep nucleus accumbens resemble pituitary receptors. Endocrinology 106: 1416-1423.

Carlsson, A., B. Falck, and N.-A. Hillarp (1962) Cellular localization of brain monoamines. Acta Physiol. Scand. 56 (Suppl. 196): 1-28.

Collu, R., P. Du Ruisseau, Y. Tache, and J. R. Ducharme (1977) Thyrotropin releasing hormone in rat brain: nyctohemeral variations. Endocrinology 100: 1391-1393.

Dannies, P. S., and M. S. Markell (1980) Differential ability of thyrotropin- and $N^{3 i m}$-methyl-thyrotropin-releasing hormone to affect prolactin and thyrotropin release in primary rat pituitary cell cultures. Edocrinology 106: 107-112.

Dluzen, D. E., and V.D. Ramirez (1983) Localized and discrete changes in neuropeptide (LHRH and TRH) and neurotransmitter (NE and DA) concentrations within the olfactory bulbs of male mice as a function of social interaction. Horm. Behav. 17: 139-145.

Dyer, R. G., and R. E. J. Dyball (1974) Evidence for a direct effect of LRF and TRF on single unit activity in the rostral hypothalamus. Nature 252: $486-488$.

Eskay, R. L., R. T. Long, and M. Palkovits (1983) Localization of immunoreactive thyrotropin releasing hormone in the lower brainstem of the rat. Brain Res. 277: 159-162.

Fallon, J. H., and R. Y. Moore (1978) Catecholamine innervation of the basal forebrain. III. Olfactory bulb, anterior olfactory nuclei, olfactory tubercle and piriform cortex. J. Comp. Neurol. 180: 533544.

Fallon, J. H., D. A. Koziell, and R. Y. Moore (1978) Catecholamine innervation of the basal forebrain. II. Amygdala, suprarhinal cortex and entorhinal cortex. J. Comp. Neurol. 180: 509-532.

Fuxe, K. (1965) Evidence for the existence of monoamine-containing neurons in the central nervous system. IV. The distribution of monoamine terminals in the central nervous system. Acta Physiol. Scand. 64: (Suppl. 247) 37-84.

Grant, G., W. Vale, and R. Guillemin (1973) Characteristics of the pituitary binding sites for thyrotropin-releasing factor. Endocrinology $92: 1629-1633$.

Heal, D. J., and A. R. Green (1979) Administration of thyrotropin releasing hormone (TRH) to rats releases dopamine in N. accumbens but not N. caudatus. Neuropharmacology 18: 23-31.

Hinkle, P. M., E. L. Woroch, and A. J. Tashjian, Jr. (1974) Receptorbinding affinities and biological activities of analogs of thyrotropinreleasing hormone in prolactin-producing pituitary cells in culture. J. Biol. Chem. 249: 3085-3090.

Hokfelt, T., K. Fuxe, O. Johansson, S. Jeffcoate, and N. White (1975a) Distribution of thyrotropin releasing hormone (TRH) in the central nervous system as revealed with immunocytochemistry. Eur. J. Pharmacol. 34: 389-392.

Hokfelt, T., K. Fuxe, S. Jeffcoate, and N. White (1975b) Thyrotropin releasing hormone (TRH)-containing nerve terminals in certain brain stem nuclei and in the spinal cord. Neurosci. Lett. 1: 133-139.

Horst, W. D., and N. Spirt (1974) A possible mechanism for the antidepressant activity of thyrotropin releasing hormone. Life Sci. 15: 1073-1082.

Jackson, I. M. D., and S. Reichlin (1974a) Thyrotropin releasing hormone (TRH): distribution in the brain, blood and urine of the rat. Life Sci. 14: 2259-2266.

Jackson, I. M. D., and S. Reichlin (1974b) Thyrotropin releasing hormone (TRH): distribution in hypothalamic and extrahypothalamic brain tissues of mammalian and submammalian chordates. Endocrinology 95: 854-862.

Kafka, M. S., A. Wirz-Justice, D. Naber, R. Y. Moore, and M. A. Benedito (1983) Circadian rhythms in rat brain neurotransmitter receptors. Fed. Proc. 42: 2796-2801.

Kalivas, P. W., and A. Horita (1979) Thyrotropin-releasing hormone: central site of action in antagonism of pentobarbital narcosis. Nature 278: 461-463.

Kalivas, P. W., and A. Horita (1980) Thyrotropin-releasing hormone: neurogenesis of action in the pentoharbital narcotized rat.. J. Pharmacol. Exp. Ther. 212: 203-210.

Kardon, F., A. Winokur, and R. D. Utiger (1977) Thyrotropin releasing hormone (TRH) in rat spinal cord. Brain Res. 122: 578-581.

Keller, H. H., G. Bartholini, and A. Pletscher (1974) Enhancement of 
cerebral noradrenaline turnover by thyrotropin releasing hormone. Nature 248: 528-529.

Kerdelhue, B., M. Palkovits, M. Karteszi, and A. Reinberg (1981) Circadian variations in substance $\mathrm{P}$, luliberin $(\mathrm{LH}-\mathrm{RH})$ and thyroliberin (TRH) contents in hypothalamic and extrahypothalamic brain nuclei of adult male rats. Brain Res. 206: 405-413.

Kreider, M. S., A. Winokur, and N. R. Krieger (1981) The olfactory bulb is rich in TRH immunoreactivity. Brain Res. 217: 69-77.

Krieg, W. J. S. (1946) Connections of the cerebral cortex. I. The albino rat. B. Structure of the cortical areas. J. Comp. Neurol. 84: 277-323.

Kubek, M. J., M. A. Lorincz, and J. F. Wilber (1977) The identification of thyrotropin releasing hormone (TRH) in hypothalamic and extrahypothalamic loci of the human central nervous system. Brain Res. 126: $196-200$.

Kubek, M. J., M. A. Rea, Z. I. Hodes, and M. H. Aprison (1983) Quantitation and characterization of thyrotropin-releasing hormone in vagal nuclei and other regions of the medulla oblongata of the rat. J. Neurochem. 40: 1307-1313.

Kuhar, M. J. (1981) Autoradiographic localization of drug and neurotransmitter receptors in the brain. Trends Neurosci. 4: 60-64.

Leppaluoto, J., F. Koivusalo, and R. Krama (1978) Thyrotropin releasing factor: distribution in neural and gastrointestinal tissues. Acta Physiol. Scand. 104: 175-179.

Lindvall, O., and U. Stenevi (1978) Dopamine and noradrenaline neurons projecting to the septal area in the rat. Cell Tissue Res. 190: 383-407.

Lindvall, O., A. Bjorkland, A. Nobin, and U. Stenevi (1974) The adrenergic innervation of the rat thalamus as revealed by the glyoxylic acid fluorescence method. J. Comp. Neurol. 154: 317-348.

Mannisto, P. T., J. Pakkanen, T. Ranta, F. Koivusalo, and J. Leppaluoto (1978) Diurnal variations of medial basal and anterior hypothalamic thyroliberin [TRH] and serum thyrotropin [TSH] concentrations in male rats. Life Sci. 23: 1343-1350.

Miyamoto, M., and Y. Nagawa (1977) Mesolimbic involvement in the locomotor stimulant action of thyrotropin-releasing hormone (TRH) in rats. Eur. J. Pharmacol. 44: 143-152.

Moore, R. Y. (1978) Catecholamine innervation of the basal forebrain. I. The septal area. J. Comp. Neurol. 177: 665-684.

Ogawa, N., Y. Yamawaki, T. Ofuji, E. Itoga, and S. Kito (1981) Discrete regional distributions of thyrotropin releasing hormone (TRH) receptor binding in monkey central nervous system. Brain Res. 205: 169-174.

Okon, E., and Y. Koch (1976) Localisation of gonadotropin-releasing and thyrotropin-releasing hormones in human brain by radioimmunoassay. Nature 263: 345-347.

Oliver, C., R. L. Eskay, N. Ben-Johnathon, and J. C. Porter (1974) Distribution and concentration of TRH in the rat brain. Endocrinology 95: 540-546.

Palacios, J. (1983) Autoradiographic visualization of receptor binding sites for thyrotropin-releasing hormone in the rodent brain. Eur. J. Pharmacol. 92: 165-166.

Palkovits, M. (1973) Isolated removal of hypothalamic or other brain nuclei of the rat. Brain Res. 59: 449-450.

Parker, C. R., Jr., and J. C. Porter (1983) Regional localization and subcellular compartmentalization of thyrotropin-releasing hormone in adult human brain. J. Neurochem. 40: 1614-1622.

Paxinos, G., and C. Watson (1982) The Rat Brain in Stereotaxic Coordinates, Academic Press, New York.

Pilotte, N. S., N. A. Sharif, and D. R. Burt (1984) Characterization and autoradiographic localization of TRH receptors in sections of rat brain. Brain Res. 293: 372-376.

Rainbow, T. C., W. V. Bleisch, A. Biegon, and B. S. McEwen (1982) Quantitative densitometry of neurotransmitter receptors. J. Neurosci. Methods 6: 127-138.

Rainbow, T. C., A. Biegon, and D. B. Berck (1984) Validation of tritium-brain-mash standards for quantitative receptor autoradiography. J. Neurosci. Methods, in press.

Renaud, L. P., and J. B. Martin (1975) Thyrotropin releasing hormone (TRH): depressant activity on cortical neuronal activity. Brain Res. 86: $150-154$.

Renaud, L. P., J. B. Martin, and P. Brazeau (1975) Depressant activity of TRH, LH-RH and somatostatin on activity of central neurones. Nature 255: 233-235.

Rostene, W. H., J.-L. Morgat, M. Dussaillant, T. C. Rainbow, and A. Sarrieau (1983) In vitro biochemical characterization and autoradiographic distribution of ${ }^{3} \mathrm{H}$-thyrotropin releasing hormone (TRH) receptors in rat brain sections. Neurosci. Abstr. 9: 171.

Schaeffer, J. M., M. J. Brownstein, and J. Axelrod (1977) Thyrotropinreleasing hormone-like material in the rat retina: changes due to environmental lighting. Proc. Natl. Acad. Sci. U.S.A. 74: 3579-3581.

Sharif, N. A., and D. R. Burt (1983) Receptors for thyrotropin releasing hormone (TRH) in rabbit spinal cord. Brain Res. 270: 259-263.

Sharif, N. A., N. S. Pilotte, and D. R. Burt (1983) Biochemical and autoradiographic studies of TRH receptors in sections of rabbit spinal cord. Biochem. Biophys. Res. Commun. 116: 669-674.

Simasko, S. M., and A. Horita (1982) Characterization and distribution of ${ }^{3} \mathrm{H}-\left(3-\mathrm{Me}-\mathrm{His}^{2}\right)$-thyrotropin releasing hormone receptors in rat brain. Life Sci. 30: 1793-1799.

Sowers, J. R., J. H. Hershman, H. E. Carlson, A. E. Pekary, M. G. Nair, and C. M. Baugh (1976a) Prolactin response to $N^{3 i m}$-methylthyrotropin releasing hormone in euthyroid subjects. J. Clin. Endocrinol. Metab. 43: 749-755.

Sowers, J. R., J. H. Hershman, A. E. Pekary, M. G. Nair, and C. M. Baugh (1976b) Effect of $N^{3 \mathrm{im}}$-methyl-thyrotropin releasing hormone on the human pituitary-thyroid axis. J. Clin. Endocrinol. Metab. 13: $741-748$.

Spindel, E., and R. J. Wurtman (1980) TRH immunoreactivity in rat brain regions, spinal cord and pancreas: validation by high-pressure liquid chromatography and thin-layer chromatography. Brain Res. 201: 279-288.

Stanton, T. L., A. Winokur, and A. L. Beckman (1980) Reversal of natural CNS depression by TRH action in the hippocampus. Brain Res. 181: 470-475.

Stanton, T. L., A. Winokur, and A. L. Beckman (1982) Seasonal variation in thyrotropin-releasing hormone (TRH) content of different brain regions and the pineal in the mammalian hibernator, Citellus lateralis. Regul. Peptides 3: 135-144.

Swanson, L. W., and B. K. Hartman (1975) The central adrenergic system. An immunofluorescence study of the location of cell bodies and their efferent connections in the rat utilizing dopamine- $\beta$-hydroxylase as a marker. J. Comp. Neurol. 163: 467-506.

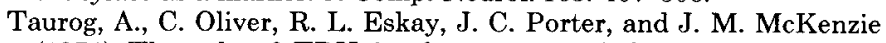
(1974) The role of TRH in the neoteny of the Mexican axolotl (Ambystoma mexicanum). Gen. Comp. Endocrinol. 24: 267-279.

Taylor, R. L., and D. R. Burt (1981) Properties of $\left[\mathrm{H}^{3}\right]\left(3-\mathrm{Me}-\mathrm{His}^{2}\right) \mathrm{TRH}$ binding to apparent TRH receptors in the sheep central nervous system. Brain Res. 218: 207-217.

'Taylor, K. L., and D. R. Burt (1982) Species differences in the regional distribution of receptor binding for thyrotropin-releasing hormone. J. Neurochem. 38: 1649-1656.

Thompson, D. F., R. L. Taylor, and D. R. Burt (1981) TRH receptor binding in avian pituitary and brain. Gen. Comp. Endocrinol. 44: $77-81$.

Unnerstall, J. R., D. L. Niehoff, M. J. Kuhar, and J. Palacios (1982) Quantitative receptor autoradiography using $\left[{ }^{3} \mathrm{H}\right]$ Ultrofilm: application to multiple benzodiazcpine receptors. J. Neurosci. Methods 6 : $59-73$.

Vale, W., J. Rivier, and R. Burgus (1971) Synthetic TRF (thyrotropin releasing factor) analogs. II. $\mathrm{pGlu}-\mathrm{N}^{3 i m} \mathrm{Me}-\mathrm{His}-$ Pro- $\mathrm{NH}_{2}$ : a synthetic analog with specific activity greater than that of TRF. Endocrinology 89: $1485-1488$.

Wei, E., S. Siegel, H. Loh, and E. L. Way (1975) 'T'hyrotropin-releasing hormone and shaking behavior in rat. Nature 253: 739-740.

Winokur, A., and A. L. Beckman (1978) Effects of thyrotropin releasing hormone, norepinephrine and acetylcholine on the activity of neurons in the hypothalamus, septum and cerebral cortex of the rat. Brain Res. 150: 205-209.

Winokur, A., and R. D. Utiger (1974) Thyrotropin-releasing hormone: regional distribution in rat brain. Science 185: 265-267.

Winokur, A., M. S. Kreider, J. Dugan, and R. D. Utiger (1978) The effects of 6-hydroxydopamine on thyrotropin-releasing hormone in rat brain. Brain Res. 152: 203-208. 